\title{
PERTUMBUHAN SEMAI KELOR (Moringa oleifera) ASAL NUSA TENGGARA TIMUR DENGAN PERLAKUAN PERBEDAAN MEDIA TUMBUH
}

\author{
(Growth of Kelor (Moringa oleifera) Seedling Origin of East Nusa Tenggara \\ With Growing Medium Treatment)
}

\author{
Hery Kurniawan ${ }^{1}$ \\ 1) Balai Penelitian dan Pengembangan Teknologi Serat Tanaman Hutan Kuok \\ Jl. Raya Bangkinang-Kuok Km.9, Kuok, Kampar, Riau 28401 \\ Email: herykurniawan2012@gmail.com
}

Diterima: 29 April 2019, Direvisi: 14 Juli 2019, Disetujui: 10 Juli 2019

DOI: https://doi.org/10.31849/forestra

\begin{abstract}
Kelor is a plant species that has many benefits because of its nutritional content. The World Health Organization (WHO) has declared Moringa as a miracle plant, because it has saved many lives, especially children in many poor countries. Kelor has the opportunity to be developed in Sumatra, especially Riau as an alternative food crop, source of some important nutrients such as vitamins, proteins and anti-oxidants. Kelor from East Nusa Tenggara (NTT) is known to have the best quality in Indonesia. Its development in Riau requires preliminary research related to the growth of seedlings in several growing medium that have characteristics similar to those in Riau. This study uses a completely randomized design with treatment of growing medium in the form of three treatments, namely black soil, podsolic soil and peat soil mixture. The analysis was carried out descriptively and inference to the parameters of the percentage of life and height of Moringa seedlings. The results showed that seedling growing medium from top soil + fuel husk were best for Moringa seedling growth. Seedling growing media from top soil + sub soil or from top soil alone can be the best alternative afterwards.
\end{abstract}

Keywords :growth, growing media, kelor

\section{ABSTRAK}

Kelor merupakan tumbuhan yang memiliki banyak manfaat karena kandungan gizinya. Badan kesehatan dunia WHO telah menyebut kelor sebagai tanaman ajaib, karena telah menyelamatkan banyak kehidupan terutama anak-anak di banyak negara miskin. Kelor berpeluang untuk dikembangkan di Sumatera khususnya Riau sebagai tanaman alternatif pangan sumber gizi penting seperti vitamin, protein, anti oksidan. Kelor asal Nusa Tenggara Timur (NTT) diketahui memiliki kualitas terbaik di Indonesia. Pengembangannya di Riau memerlukan penelitian awal terkait dengan pertumbuhan semainya pada beberapa media tumbuh yang memiliki karakteristik serupa dengan tanah di Riau.Tujuan penelitian ini adalah untuk mengetahui komposisi media tumbuh terbaik bagi pertumbuhan semai kelor asal NTT. Penelitian ini menggunakan rancangan acak lengkap dengan 
perlakuan media tumbuh berupa tiga perlakuan, yakni tanah hitam, tanah podsolik dan campuran tanah gambut. Analisis dilakukan secara deskriptif dan inferensi terhadap parameter persen hidup dan tinggi semai kelor. Hasil penelitian menunjukkan media tumbuh semai dari top soil + sekam bakar adalah terbaik untuk pertumbuhan semai kelor. Media tumbuh semai dari top soil + sub soil atau dari top soil saja bisa menjadi alternatif terbaik setelahnya.

Kata kunci : pertumbuhan, media tumbuh, kelor

\section{PENDAHULUAN}

Tanaman kelor dikenal dengan berbagai nama daerah, seperti murong (Aceh), munggai (Sumatera Barat), kilor (Lampung), kelor (Jawa Barat dan Jawa Tengah), marongghi (Madura), kiloro (Bugis), parongge (Bima), kawano (Sumba), marungga/hau fo (Timor), moltong (Flores)dan kelo (Ternate). Sebaran kelor sangat luas mulai dari Asia, Afrika, dan Amerika (Harryana et al., 2013). Di Indonesia kelor tersebar mulai dari Sumatera hingga Papua. Bahkan Menteri Kesehatan RI Nila Moeloek, telah merekomendasikannya sebagai penyelamat gizi buruk di Papua khususnya Asmat (Anonim, 2018).

Kelor merupakan tumbuhan yang memiliki kandungan gizi yang tinggi baik kandungan nutrisi mikro maupun mikro, sehingga kelor bukan hanya merupakan sumber nutrisi pangan namun juga memiliki efek secara farmakologi (Aminah et al., 2015). Lebih dari itu kelor juga memiliki manfaat lingkungan yang sangat penting bagi kehidupan.Kemampuannya untuk hidup pada lahan kering ataupun marginal, menjadikan kelor sebagai tanaman penyelamat lingkungan sekaligus penyelamat gizi dan kesehatan masyarakat yang hidup pada wilayah kering. Kelor juga memiliki khasiat sebagai penjernih air, bagian yang digunakan biasanya daun ataupun biji kelor.Kemampuan ini semakin melengkapi fungsi kelor sebagai penyelamat kehidupan.
Sumatera merupakan salah satu penghasil tanaman kelor yang bermanfaat. Beberapa lokasi seperti di Dumai, mulai dikembangkan menjadi sentra pertanian termasuk kelor. Kelor bukan hanya menjadi produk untuk konsumsi rumah tangga saja, namun di pasaran termasuk pasar internasional, kelor ternyata memiliki tingkat permintaan yang cukup tinggi. Wasonowati dan kawan-kawan (2017) menyatakan bahwa kelor mempunyai prospek bagus untuk dikembangkan serta mempunyai nilai ekonomis yang tinggi dan berpotensi untuk peningkatan pendapatan masyarakat.Pada level internasional, investor dari Spanyol dan Tiongkok berminat untuk membeli daun kelor asal NTT (Anonim, 2014).

Penanaman kelor saat ini banyak dilakukan di NTT khususnya Pulau Timor. Peluang pasar yang tinggi dan manfaat yang menjanjikan dari kelor ini perlu diimbangi dengan pencarian informasi dan teknologi untuk meningkatkan kualitas dan kuantitas tanaman kelor yang masih perlu dikembangkan hingga diperoleh tanaman kelor yang unggul. Penelitian ini merupakan penelitian di tingkat persemaian dengan maksud untuk mengetahui sejauh mana kelor asal NTT mampu tumbuh di Sumatera khususnya Riau. Secara lebih spesifik penelitian ini ditujukan untuk mengetahui komposisi media tumbuh terbaik bagi pertumbuhan semai kelor asal NTT. 


\section{METODE PENELITIAN}

Penelitian ini dilakukan di persemaian milik Balai Penelitian dan Pengembangan Teknologi Serat Tanaman Hutan Kuok, pada bulan Januari sampai dengan bulan April tahun 2018. Bahanbahan yang digunakan adalah media semai dengan empat macam perlakuan, polibag, dan bibit kelor asal NTT. Alat-alat yang digunakan adalah alat ukur tinggi berupa mistar dan caliper untuk mengukur diameter bibit, serta alat tulis untuk pencatatan data pengukuran.

Penelitian ini menggunakan metode eksperimental kuantitatif, dengan desain penelitian menggunakan rancangan acak lengkap (RAL). Faktor perlakuan yang digunakan adalah tunggal yakni media tumbuh semai, dengan variasi perlakuannya sebanyak empat perlakuan, sebagai berikut :

$\mathrm{A} 0=$ media top soil

$\mathrm{A} 1=$ media top soil + sekam padi bakar

$\mathrm{A} 2=$ media top soil + sub soil

$\mathrm{A} 3=$ media gambut

Seluruh semai dengan masingmasing perlakuan diukur tinggi dan diameter bibit untuk mendapatkan parameter tinggi dan diameter bibit kelor.Selain itu persen tumbuh juga dihitung berdasarkan rasio jumlah kecambah/bibit yang tumbuh dengan benih yang tidak tumbuh.Analisis dilakukan secara statistik dengan metode deskriptif maupun inferensi. Analisis statistik secara inferensi dilakukan menggunakan uji F, dan dilanjutkan dengan uji lanjut menggunakan Duncan Multiple Range Test (DMRT) atau uji perbandingan berganda Duncan (Nazir, 2013).

\section{HASIL DAN PEMBAHASAN}

Kelor (Moringa oleifera Lam) merupakan tanaman yang memiliki daerah penyebaran sangat luas dan diyakini berasal dari dataran India (Muluvi G. et al., 1999). Tanaman yang banyak ditanam sebagai tanaman pagar di pekarangan dan kebun ini, dikenal dengan istilah tanaman ajaib yang memiliki banyak manfaat (Fuglie, 2001). Manfaat tersebut antara lain sebagai sumber vitamin A sebanyak empat kali wortel, vitamin $\mathrm{C}$ sebanyak tujuh kali dari jeruk, kalsium sebanyak empat kali susu dan minyak bijinya digunakan sebagai alternatif bahan baku pengganti solar (Krisnadi, 2015).

Benih kelor yang digunakan dalam penelitian ini berasal dari Pulau Timor, Provinsi NTT. Benih kelor yang diperoleh kemudian disemaikan di pesemaian permanen Balai Penelitian dan Pengembangan Teknologi Serat Tanaman Hutan (BP2TSTH), untuk mendapatkan bibit kelor yang akan diteliti. Media tumbuh disiapkan di polibag dengan empat macam perbedaan sebagai perlakuan $(\mathrm{A} 0=$ top soil ; $\mathrm{A} 1=$ top soil + sekam padi bakar ; $\mathrm{A} 2=$ top soil+sub soil; $A 3=$ gambut). Bibit kelor ditabur secara langsung ke dalam polibag. Selanjutnya pertumbuhan kelor diukur pada saat kelor mencapai umur 1 bulan setelah tanam, 2 bulan setelah tanam, dan 3 bulan setelah tanam (bst). Hasil pengukuran tinggi semai kelor untuk keempat perlakuan media tumbuh pada saat 1 bst, 2 bst dan 3 bst, dapat dilihat pada gambar 1 di bawah ini. 


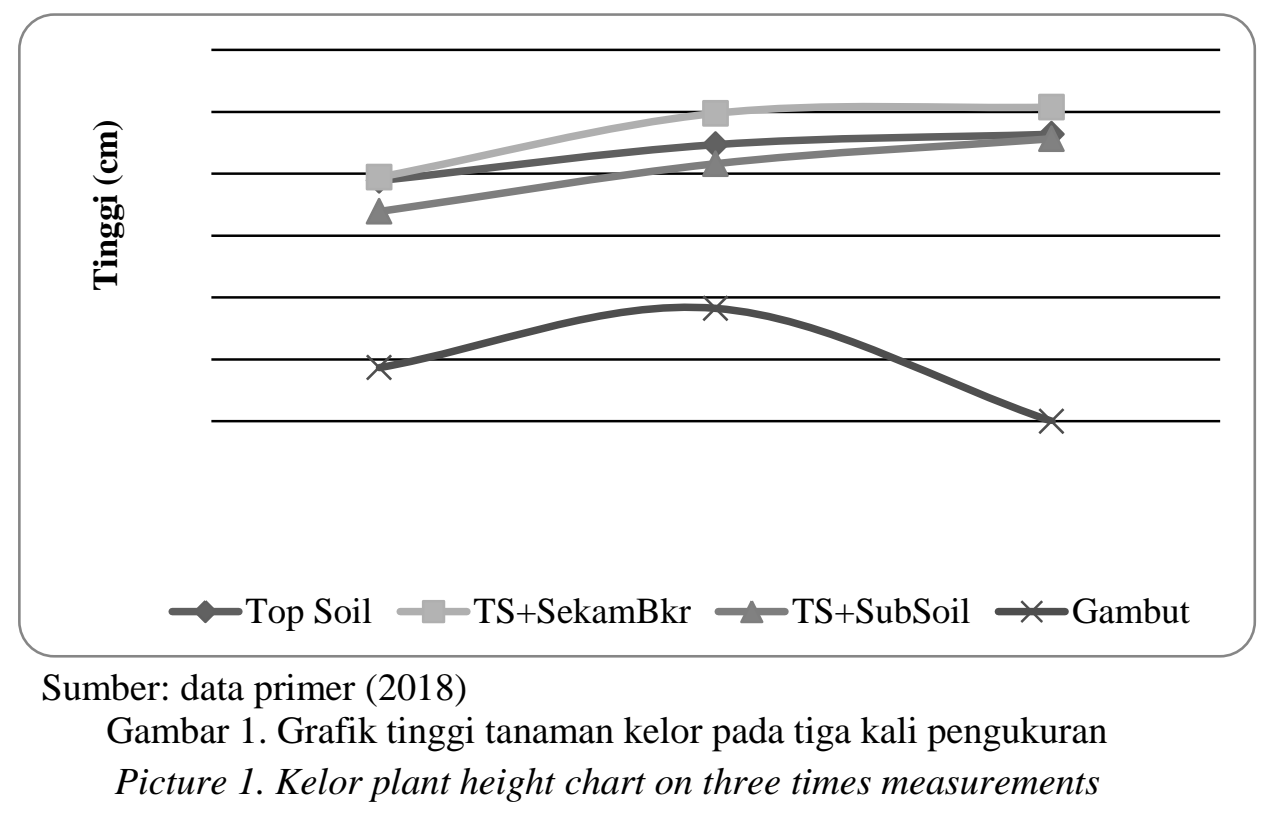

Berdasarkan hasil pengukuran tinggi bibit yang disajikan dalam bentuk grafik pada gambar 1 di atas, diketahui bahwa media top soil + sekam bakar memiliki grafik pertumbuhan tinggi terbaik. Pada saat satu bulan setelah tanam (1 bst), tingginya dapat dikatakan sama dengan tinggi kelor menggunakan media top soil saja, yakni $39,45 \mathrm{~cm}$. Pada saat mencapai umur 2 bst, tingginya mencapai 49,77 cm, terjadi penambahan tinggi sekitar $10,32 \mathrm{~cm}$. Sementara untuk semai menggunakan media top soil saja,pada umur 2 bst tingginya baru mencapai $44,7 \mathrm{~cm}$, terdapat perbedaan sekitar $5 \mathrm{~cm}$ antara media tumbuh top soil + sekam bakar dengan media top soil saja.Pada saat umur 3 bst, terjadi penambahan tinggi $\pm 1 \mathrm{~cm}$ untuk semai dengan media top soil + sekam bakar, sedangkan untuk mediatop soil saja terjadi penambahan sekitar $1,68 \mathrm{~cm}$. Terdapat perbedaan tinggi total pada umur 3 bst sekitar $3 \mathrm{~cm}$ antara media top soil dengan TS + sekam bakar.
Beberapa kemungkinan yang menyebabkan tinggi tanaman kelor menggunakan top soil + sekam padi lebih cepat pertumbuhannya adalah adanya pengaruh pada faktor aerasi dan porositas media semai yang menggunakan sekam padi.Sekam padi merupakan media yang berasal dari limbah penggilingan padi yang memiliki sifat ringan, porous dan bersih (Hayati 2006). Sedangkan menurut (Gustia 2013), penggunaansekam padi bakar pada media tanam dapat memperbaiki sifat fisik dan kimia tanah, serta melindungi tanaman.Selain itu dengan penambahan sekam padi drainase serta aerasi akan meningkat, Hal ini disebabkan sekam bakar lebih porous karena memiliki pori-pori makro dan mikro yang hampir seimbang, sehingga sirkulasi udara yang dihasilkan cukup baik serta memiliki daya serap air yang tinggi (Wuryan, 2008). Selain itu, masih menurut Wuryan (2008), komposisi kimiawi sekam bakar adalah $\mathrm{SiO}_{2}$ dengan kadar 52\% dan C sebanyak 31\%. Sementara kandungan lainnya terdiri dari $\mathrm{Fe}_{2} \mathrm{O}_{3}, \mathrm{~K}_{2} \mathrm{O}$, 
$\mathrm{MgO}, \mathrm{CaO}, \mathrm{MnO}$, dan $\mathrm{Cu}$ dengan jumlah yang kecil serta beberapa bahan organik lainnya.Lebih lanjut hasil penelitian (Gustia, 2013) menunjukkan bahwa penambahan sekam bakar pada media tanam tanah menunjukkan hasil yang lebih baik dibandingkan dengan tanpa penambahan sekam bakar. Hasil penelitian (Sawaludin et al., 2018) juga menunjukkan bahwa media terbaik untuk pertumbuhan bibit kelor adalah media tanah yang ditambah dengan arang sekam.

Pada tabel terlihat bahwa tingkat pertumbuhan tertinggi adalah menggunakan media top soil + sekam padi, selanjutnya berturut-turut adalah menggunakan media top soil saja, diikuti oleh media top soil + sub soil, dan berikutnya yang terakhir adalah menggunakan media gambut. Media top soil dan sub soil dalam penelitian ini diketahui tidak memberikan efek yang signifikan, bahkan cenderung terjadi pengurangan hasil. Apabila media top soil saja dianggap sebagai kontrol maka hasil yang diperoleh pada semai kelor menggunakan media top soil + sub soil, adalah di bawah kontrol. Sebagaimana diketahui bahwa media top soil pada umumnya memiliki kandungan hara yang cukup tinggi dibandingkan media sub soil yang ada di bawahnya (Harahap, 2010; Winarso, 2005). Pencampuran media top soil dengan sub soil diduga kuat akan mengurangi kandungan hara dan nutrisi yang diperlukan oleh tanaman. Selain itu, menurut Hidayat dan kawan-kawan 2007, tanah subsoil yang padat dapat menyebabkan pergerakan air di dalam tanah sangat lambat sehingga air sulit masuk ke dalam lapisan di bawahnya. Sedangkan menurut Hardjowigeno (2003) tanah yang mempunyai berat isi tinggi akan sulit meneruskan air atau sukar ditembus akar tanaman, sebaliknya tanah dengan berat isi rendah, akar tanaman lebih mudah berkembang. Pengurangan hasil pertumbuhan tinggi pada semai kelor yang menggunakan media top soil + sub soil diduga kuat karena adanya pengurangan ketersediaan unsur hara atau nutrisi yang diperlukan tanaman serta meningkatnya berat isi tanah.

Namun demikian, pengamatan parameter tinggi ini dilakukan hanya sampai 3 bulan setelah tanam. Melihat tren grafik pertumbuhan tinggi kelor pada gambar 1 di atas, maka terlihat grafik pertumbuhan tinggi semai kelor dengan media top soil + sub soil masih cenderung naik. Sedangkan tren grafik pertumbuhan semai kelor dengan media top soil terlihat sudah cenderung melandai (datar). Pada analisis ragam dengan menggunakan uji $\mathrm{F}$ statistik, diketahui hasil pertumbuhan tinggi semai kelor antara yang menggunakan media top soil dengan top soil + sub soil, secara statistik tidak berbeda nyata. Perbedaan nyata terdapat pada pertumbuhan tinggi semai dengan media top soil + sekam bakar (tertinggi) terhadap semua perlakuan lainnya. Demikian juga untuk semai menggunakan media gambut (terendah) berbeda nyata dengan semuanya.Secara lengkap hasil uji statistik dapat dilihat pada tabel 1 di bawah ini. 
Tabel 1. Hasil Uji F Tinggi Semai Kelor

Table 1.F test Result of Kelor Seedling Height

\begin{tabular}{lrrrrr}
\hline & \multicolumn{1}{c}{ JK } & Db & KT & F & Sig. \\
\hline Antar kelompok & 141722,47 & 3 & 47240,82 & 1009,55 & 0,000 \\
\hline Dalam kelompok & 14506,14 & 310 & 46,79 & & \\
\hline Total & 156228,61 & 313 & & & \\
\hline
\end{tabular}

Berdasarkan tabel 1, diketahui bahwa terdapat perbedaan yang nyata terhadap tinggi semai kelor dengan perlakuan media tumbuh yang berbedabeda. Selanjutnya untuk mengetahui perbedaan pada tiap perlakuan, dilakukan uji lanjut menggunakan metode Duncan Multiple Range Test (DMRT). Hasil uji lanjut pada tabel 2, menunjukkan bahwa terdapat 3 subset yang berbeda, artinya terdapat 3 kelompok hasil tinggi semai kelor yang satu sama lain berbeda secara
statistik.Subset pertama adalah untuk media gambut yang berbeda nyata dengan seluruh perlakuan lainnya. Subset kedua adalah untuk media topsoil+subsoil dan media topsoil saja. Kedua perlakuan ini tidak berbeda nyata secara statistik, namun berbeda nyata dengan perlakuan lainnya. Selanjutnya subset yang terakhir adalah untuk media tumbuh topsoil+sekam bakar yang berbeda nyata dengan semua perlakuan lainnya.

Tabel 2. Hasil Uji Lanjut Perbedaan Tinggi Semai Kelor

Table 2. Post hoc Test Result of Kelor Seedling Height Differences

\begin{tabular}{|c|c|c|c|c|c|}
\hline & \multirow[b]{2}{*}{ Media } & \multirow[b]{2}{*}{$\mathrm{N}$} & \multicolumn{3}{|c|}{ Subset for alpha $=0,05$} \\
\hline & & & 1 & 2 & 3 \\
\hline \multirow[t]{5}{*}{ Duncan $^{\mathrm{a}, \mathrm{b}}$} & Gambut & 84 & 0,00 & & \\
\hline & TopSoil+SubSoil & 87 & & 45,65 & \\
\hline & Top Soil & 69 & & 46,37 & \\
\hline & TopSoil+SekamBkr & 74 & & & 51,45 \\
\hline & Sig. & & 1,00 & 0,51 & 1,00 \\
\hline
\end{tabular}

Pengamatan terhadap tinggi bibit kelor yang menggunakan media tumbuh tanah gambut, diketahui pertumbuhannya adalah paling rendah yakni pada saat 1 bst mencapai $8,68 \mathrm{~cm}$ dan saat umur $2 \mathrm{bst}$ hanya mencapai $18,25 \mathrm{~cm}$. Pada saat mencapai umur 3 bst seluruh bibit kelor yang menggunakan media tanam tanah gambut mengalami kematian seluruhnya.
Kematian ini diduga kuat karena tanaman kelor kurang mampu beradaptasi dengan kondisi tanah yang asam. Menurut Krisnadi (2015) persyaratan tumbuh untuk kelor diantaranya adalah media tumbuh berupa tanah berpasir atau lempung berpasir dengan $\mathrm{pH}$ tanah berkisar antara 59. Kondisi tanah gambut yang asam menjadikan tanaman kelor tidak dapat tumbuh dengan baik bahkan pada akhirnya mengalami kematian yang cepat. 


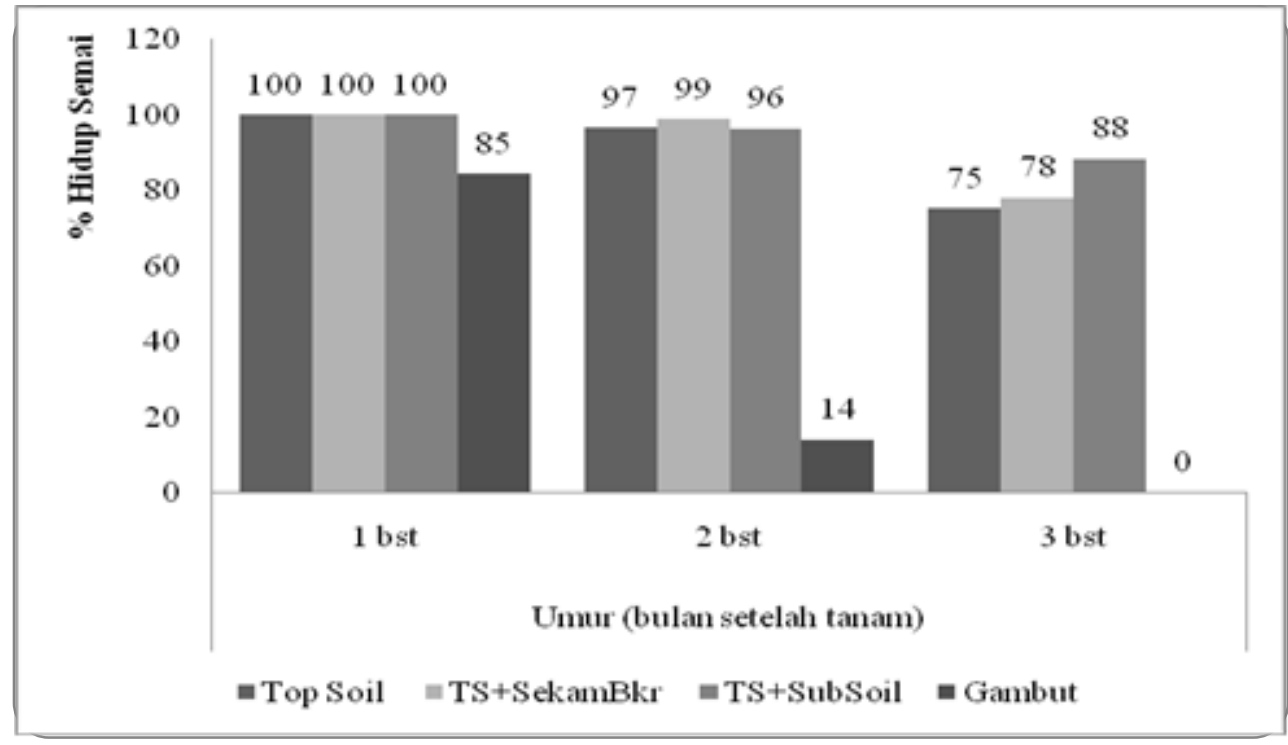

Gambar 2. Grafik persen hidup tanaman kelor pada 3 kali pengukuran

Picture 2. Chart of Kelor life percentage on three times measurements

Pengamatan persen hidup semai kelor dapat dilihat pada gambar 2 di atas. Berdasarkan pengamatan terhadap persen hidup semai pada 1 bst, 2 bst dan 3 bst, diketahui pada saat 1 bst persen hidup belum terpaut cukup jauh. Hanya pada media gambut persen hidup pada 1 bst yang angkanya berbeda. Selanjutnya perbedaan persen hidup semakin meningkat dengan bertambahnya usia semai. Bahkan pada 3 bst, persen hidup semai dengan media gambut adalah 0 , atau mati semua. Persen hidup tertinggi saat sudah mencapai 3 bst adalah pada semai yang menggunakan media top soil + sub soil yakni $88,39 \%$. Selanjutnya adalah pada semai menggunakan media top soil + sekam padi yakni $78,1 \%$. Sedangkan semai dengan media top soil persen hidupnya mencapai $75,27 \%$.Kematian seluruh semai kelor dengan media gambut diduga kuat karena tingkat keasaman media gambut yang melebihi persyaratan tumbuh kelor yakni 5-
9 (Krisnadi, 2015; (Palada M. \& Chang L, 2003)

Berbeda dengan hasil pengamatan tinggi, pada parameter persen hidup tanaman, media top soil + sub soil menghasilkan nilai tertinggi untuk persen hidup. Selanjutnya adalah media top soil + sekam padi di peringkat kedua. Perbedaan persen tumbuh antara semai yang menggunakan media top soil + sub soil dengan yang menggunakan media top soil + sekam padi adalah $10 \%$. Perbedaan ini diduga kuat karena sifat tanaman kelor yang kurang cocok dengan media yang terlalu kuat mengikat air. Hasil penelitian Sawaludin dan kawan-kawan (2018) menunjukkan bahwa media tanah+sekam memiliki kemampuan mengikat air tertinggi.Tanah subsoil jenis ultisol (sebagian besar Riau) memiliki kandungan bahan organikyang rendah dengan kemampuan mengikat air yang rendah, sedangkan tanah top soil memiliki kandungan bahan organik yang cukup 
tinggi pada umumnya sehingga akan meningkatkan kemampuan mengikat airnya (Utama Nst R. et al., 2015). Sedangkan menurut (Amri et al., 2014), pada umumnya top soil banyak mengandung bahan organik dan memiliki kerapatan yang lebih kecil dari sub-soil, hal ini disebabkan bahan organik pada tanah top soil lebih ringan daripada partikel padat tanah mineral pada sub soil dalam volume yang sama. Sehingga porositas dan kemampuan mengikat air pada tanah top soil lebih tinggi daripada tanah subsoil. Meskipun demikian pada media top soil + sekam, kelor masih mampu tumbuh dengan baik, dengan adanya pengurangan daya mengikat air karena peningkatan porositas media oleh sekam padi. Bahkan dengan kandungan nutrisi yang lebih dibandingkan tanah subsoil, maka semai kelor mampu tumbuh dengan tinggi tanaman di atas semai yang menggunakan media top soil + sub soil. Sehingga kematian semai pada semai yang menggunakan top soil + sekam padi diduga kuat karena media yang terlalu basah memicu munculnya kebusukan pada akar.

\section{KESIMPULAN}

Berdasarkan pembahasan di atas dapat disimpulkan bahwa semai atau bibit kelor mampu tumbuh dengan baik pada media tumbuh dari top soil, top soil + sekam padi dan top soil + sub soil. Namun, secara statistik dapat dinilai bahwa media terbaik untuk pembibitan kelor adalah dengan menggunakan media top soil + sekam bakar, karena memiliki peringkat yang cukup stabil berdasarkan pengamatan parameter tinggi dan persen hidup. Pertumbuhan tinggi lebih dipengaruhi oleh kesuburan medianya, sedangkan persen hidup lebih dipengaruhi oleh kemampuan media mengikat dan melepaskan air dalam media.

\section{UCAPAN TERIMAKASIH}

Ucapan terimakasih saya ucapkan kepada Bapak Arifin Budi Siswanto dan Bapak Sunarto yang telah banyak membantu selama kegiatan penelitian ini, terutama terkait kegiatan persemaian dan pengukuran bibit.

\section{DAFTAR PUSTAKA}

Aminah, S., Ramdhan, T. \& Yanis, M., 2015. Kandunga Nutrisi dan Sifat Fungsional Tanaman Kelor (Moringa oleifera). Buletin Pertanian Perkotaan, 5(2), pp.35-44.

Amri, S., Nasrul, B. \& Armaini, 2014. Tingkat Kerusakan Tanah Akibat Produksi Biomassa Pertanian di Kecamatan Kuala Cenaku Kabupaten Indragiri Hulu. Jom Faperta, 1(2).

Anonim, 2018. Daun Kelor Bisa Jadi Solusi Gizi Buruk di Asmat. Available at: www.life.trubus.id.

Anonim, 2014. Fakta dan Mitos Mistis Soal Daun Kelor yang Melegenda. Available at: www.quranichealing.com. [Accessed March 8, 2018].

Fuglie, L.J., 2001. The Miracle Tree: The multiple attributes of moringa, Dakar, Senegal: Church World Service.

Gustia, H., 2013. Pengaruh Penambahan Sekam Bakar Pada Media Tanam Terhadap Pertumbuhan dan Produksi Tanaman Sawi (Brassica juncea L.). EJournal WIDYA Kesehatan dan Lingkungan, 1(1), pp.12-17.

Harahap, O.A., 2010. Pemanfaatan Kompos Tandan Kosong Kelapa Sawit Dan 
Konsentrat Limbah Cair Pabrik Kelapa Sawit Untuk Memperbaiki Sifat Kimia Media Tanam Sub Soil Ultisol Dan Pertumbuhan Bibit Kelapa Sawit (Elaeis guineensis Jacq.). Universitas Sumatera Utara.

Hardjowigeno, S., 2003. Ilmu Tanah, Jakarta: Akademikan Pressindo.

Harryana, E. et al., 2013. Daun Ampuh Basmi Berbagai Penyakit, Jogjakarta: Nusa Creativa.

Hayati, M., 2006. Penggunaan Sekam Padi sebagai Media Alternatif dan Pengujuian Efektivitas Penggunaan Media Pupuk Daun Terhadap Pertumbuhan dan Hasil Tanaman Tomat Secara Hidroponik. Jurnal Floratek, 2, pp.63-68.

Hidayat, T.C. et al., 2007. Pengaruh Pemanfaatan Berbagai Limbah Pertanian untuk Pembenah Media Tanam Bibit Kelapa Sawit. Jurnal Penelitian Kelapa Sawit, 15(2), pp.185-193.

Krisnadi A., D., 2015. Kelor Super Nutrisi, Jakarta: Morindo.

Muluvi G., M. et al., 1999. Amplified Fragment Length polymorphism ( AFLP ) Analysis of Genetic Variation in Moringa oleifera Lam . Molecular Ecology, 8, pp.463-470.

Nazir, M., 2013. Metode Penelitian, Bogor: Ghalia Indonesia.

Palada M., C. \& Chang L., C., 2003. Suggested Cultural Practices for Moringa. , (AVRDC pub\#03-545). Available at: http://miracletrees.org/ [4 Oktober 2015].

Sawaludin, Nikmatullah, A. \& Santoso,
B.B., 2018. Pengaruh Berbagai Macam Media terhadap Pertumbuhan Bibit Kelor ( Moringa oleifera Lam .) Asal Stek Batang. Jurnal Sains Teknologi dan Lingkungan, 4(1), pp.31-42.

Utama Nst R., A., Ardian \& En Yulia, A., 2015. Pengaruh Campuran Subsoil Ultisol dengan Kompos TKKS sebagai Media Tanam dan Voume Penyiraman Terhadap Pertumbuhan Bibit Kelapa Sawit (Elaeis guineensis Jacq.) di Pembibitan Utama. Jom Faperta, 2(2). Available at: http://miracletrees.org/ [4 Oktober 2015].

Wasonowati, C. et al., 2017. Kajian Budidaya Tanaman Kelor (Moringa oleifera Lamk) sebagai Sayuran dan Pangan Alternatif di Madura. In Yogyakarta: Fakultas Pertanian Universitas Gadjah Mada, pp. 43-48.

Winarso, S., 2005. Kesuburan Tanah, Dasar Kesehatan dan Kualitas Tanah Pertama., Yogyakarta: Gava Media.

Wuryan, 2008. Pengaruh Media Sekam Padi Terhadap Pertumbuhan Tanaman Hias Pot Spathiphyllum sp. Buletin Penelitian Tanaman Hias. Jurnal Hortikultura, 2(2), pp.81-89.

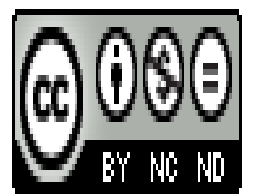
(C) 2019 Wahana Forestra: Jurnal Kehutanan. All rights reserved. This is an open access article distributed under the terms of the BY NC - ND License (https://creativecommons.org/licenses/by-nc$\underline{\mathrm{nd} / 4.0 /) \text {. }}$ 